\title{
Political Ethics and Public Style in the Early Career of Jersey City's Frank Hague
}

\author{
Matthew Taylor Raffety ${ }^{1}$
}

\begin{abstract}
This essay charts the political rise of Frank Hague, Jersey City's infamous mayor from 1917-1947. Although most historical attention focuses on his long tenure as mayor, Hague's pre-mayoral career provides an instructive example of how urban politicians used public spectacle, the media, ethnic identity, and middle class mores to redefine American urban politics. Before becoming mayor, Hague crafted a public persona that appealed to both middle-class and working-class ethnic voters by reinventing himself as a Progressive while still retaining the showmanship and personal appeals of machine politics. Hague straddled two distinct political traditions, presenting himself simultaneously as a "pol," rooted in the historical mores of the "Horseshoe," his home neighborhood, as well as a good government advocate, appealing to Jersey City's native-born middle class - focusing on clean water, public safety, and personal responsibility. In doing so, Hague provided a template for ethnic reform mayors who followed, from Fiorello LaGuardia and Richard Daley to Rudolph Giuliani and Ed Rendell.
\end{abstract}

"For better or worse, he knew how to run a show."2

Of all the political bosses who ruled the cities of the American East and Midwest at the beginning of the twentieth century, perhaps none was as feared, demonized, and beloved as Frank Hague of Jersey City, New Jersey (Figure 1). Curiously, however, the man who commanded the attention of contemporaries has received scant attention since his machine was "buried" with a symbolic funeral in May of $1949 .^{3}$

Contemporaries and historians describe Hague (1876-1956) as the archetypal American political boss. His tenure as mayor from 1917 to 1947 was rarely contested, and his power is accurately described by his most famous (if quoted out of context) assertion, "I am the law." His control of Jersey City's police department drew comparisons to Hitler's Gestapo from contemporary critics. Throughout his career, Hague remained unhesitating in his use of political power, political spectacle, and, when necessary, physical violence. Both the style and the substance of Hague's agenda were innovative. By reinventing himself as a Progressive, while retaining the dramatic political flair of machine politics,

\footnotetext{
${ }^{1}$ Matthew Taylor Raffety received his Ph.D. from Columbia University in 2003 and currently serves as Assistant Professor of History at the University of Redlands in Redlands, CA. He is completing a book on American seafarers appearing in federal court before the Civil War.

${ }^{2}$ Senator Joseph W. Tumulty, "Frank Hague, Cause and Effect" (lecture, St. Peter's College, Jersey City, New Jersey 3 February 1981), 11, Frank Hague Collection, Jersey City Public Library (hereafter cited as Hague Collection).

3 “Hague's Fall Set Standard for the Legends," Jersey Journal, February 27, 1989.

${ }^{4}$ Hague had, in fact, been outlining his anti-juvenile delinquency "Save the Boy Program" and was suggesting that deviating from the strict reading of the law in order to keep children in school and out of prison where their fate as permanent criminals would be sealed was justified. Tumulty, "Frank Hague, Cause and Effect," 7-8; Frank Hague, speech delivered at Wildwood, New Jersey October 26, 1934, Collection of the Jersey City Historical Project.
} 
Hague created an appeal that transcended class and ethnicity. He expanded the reach of the Progressive agenda of cleanliness, order, and the curtailing of vice into the ethnic working class, who viewed politics as a spectator sport, and introduced the style of IrishAmerican politics to Jersey City's largely Protestant, native-born middle class, who focused on reform and "good government."

William V. Shannon has suggested that the bosses represented "a set of political ethics and an attitude toward politics and power strikingly different from the native middle class code." 6 Over time, Hague developed an approach that appealed to both sets of political ethics. By finding issues that could transcend the class and ethnic cultural divide and by packaging Progressive reform as bold political spectacle, Hague created a political agenda and style that propelled him to leadership and maintained him there for more than three decades. Additionally, Hague's rise coincided with the zenith of the penny press. Hague's use of media was masterful, and he knew that any gesture or battle played better with a reporter handy. He developed a symbiotic relationship with the press. Even those papers, including the Hudson Observer, that were hostile to him, understood that covering Hague sold papers, and Hague understood that even negative press kept his face and his agenda in front of voters.

The significance of Hague's rough-and-tumble Progressivism extends well beyond the confines of Jersey City, as he marked the creation of a lasting and lastingly important archetype of urban politics. From his own era, in the likes of Fiorello LaGuardia and Al Smith across the Hudson, to more recent ethnic reform mayors such as Boston's Ray Flynn and New York's Rudolph Giuliani, Hague's early career serves as a template for how to fuse a reform agenda aimed at middle-class morality to the political showmanship and credibility of ethnic political style. Scholarship focusing on Hague is limited, particularly that which deals with his pre-mayoral career. ${ }^{7}$ Most often journalists have used Hague's long and powerful tenure as mayor as an object lesson about the evils of bossism. ${ }^{8}$ If Hague himself has not been adequately examined, however, the larger phenomenon of bossism and machine politics is well-worn historiographic terrain.

\footnotetext{
${ }^{5}$ For the broad ideological contours of middle-class Progressivism, see Robert H. Wiebe, The Search for Order, 1877-1920 (New York: Hill and Wang, 1967).

${ }^{6}$ William V. Shannon, The American Irish, (New York: Macmillan, 1973), 63.

${ }^{7}$ Of four monographs on Hague, only two, journalist Dayton David McKean's The Boss: The Hague Machine in Action (Boston: Houghton Mifflin, 1940) and former Jersey City Mayor Thomas F. X. Smith's The Powerticians (Secaucus, NJ: Lyle Stuart, 1982), deal meaningfully with Hague's earlier career. Mark Foster, "The Early Career of Mayor Frank Hague" (master's thesis, University of Southern California, 1968), remains the canonical text on Hague's pre-mayoral career. See also Foster's article on the same topic, "Frank Hague of Jersey C ity: The 'Boss' as Reformer," New Jersey History 86, no. 2 (1968): 10617. More recently, local author and director of the Jersey City Historical Project Bob Leach has focused on Hague folklore and has published The Frank Hague Picture Book, in the hope that it might "inspire another writer to undertake the much needed definitive study of the subject." Bob Leach, The Frank Hague Picture Book (Jersey City, NJ: Jersey City Historical Project, 1998), iv. Additionally, Leach has drafted several excellent short pieces dramatizing major events in Hague's career.

${ }^{8}$ The premier monograph example of anti-Hague polemic is George C. Rapport's The Statesman and the Boss (New York: Vantage, 1961), which dramatizes the political and ethical differences between Woodrow Wilson (the "statesman") and Hague ("the boss"). Rapport, McKean, and the authors in the Nation had far more interest in providing a dramatic political lesson for their own era than in historicizing the events they described and usually pointed to Hague's early career only to seek the seeds of the "monster" he became.
} 


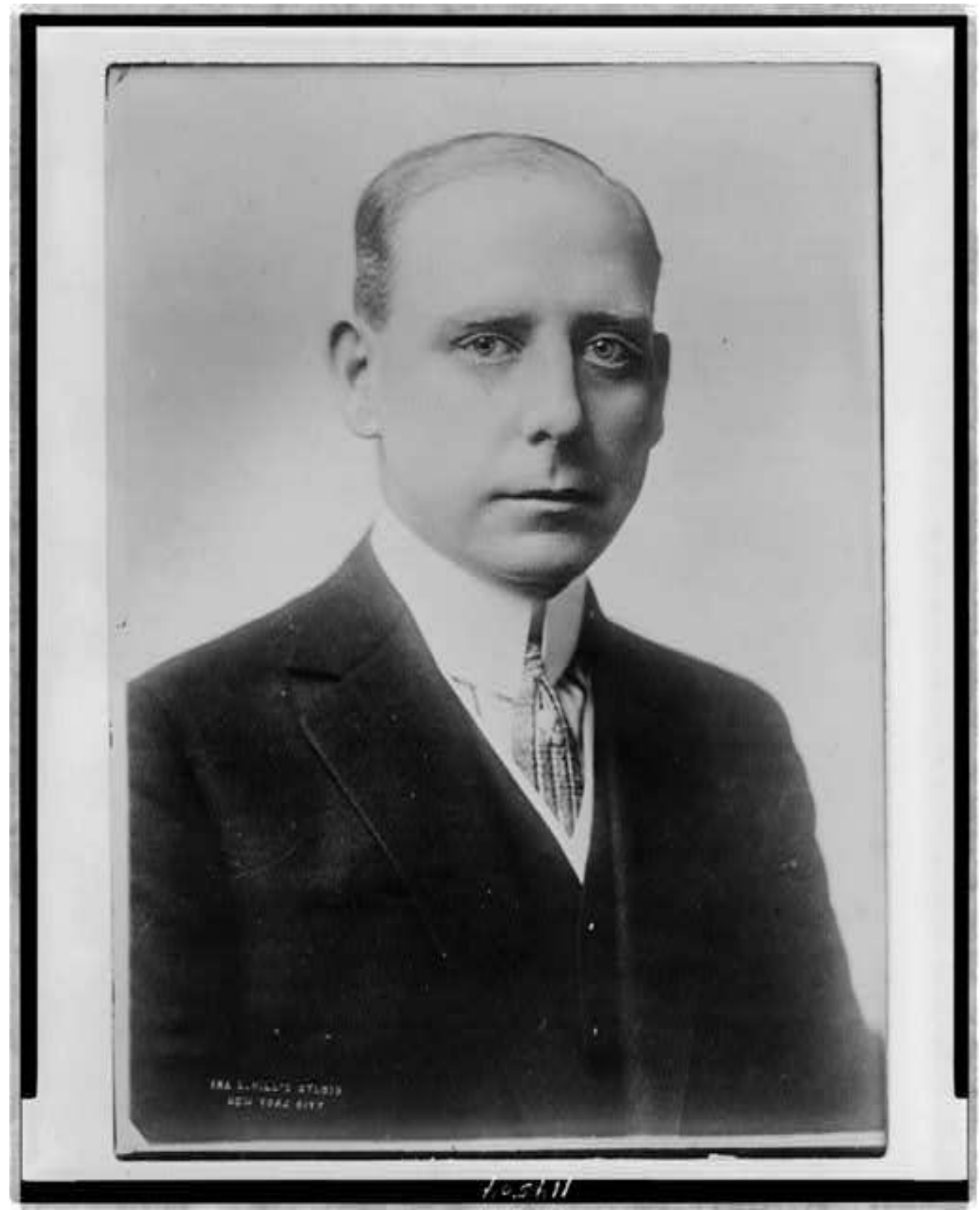

Figure 1. Frank Hague, ca. 1920. Reproduction Number: LC-USZ62-119504, Library of Congress Prints and Photographs Division Washington, D.C.

The Nation in particular, held Hague up as a symbol of corruption. He was the subject of a series of negative articles between 1929 and 1949, including L.H. Patterson, "Mayor Hague, Boss of Jersey City," Nation, May 29, 1929, 643-44; Alfred H. Hirsch "Scab City New Jersey," Nation, October 31, 1934, 50911; Alfred H. Hirsch, "Scab City II", Nation, November 7, 1934, 538-40; McAllister Coleman, "HagueWorried Dictator," Nation, December 28, 1937, 29-31; McAlister Coleman, "Hague's Army Falls Back," Nation, December 14, 1940, 605-6; Will Chasan, "Hague on the Run," Nation, August 2, 1940, 89-90; McAlister Coleman, "John Longo and Frank Hague," Nation, January 1, 1944, 4-15; McAlister Coleman, "Longo vs. Hague - Third Round," Nation, January 2, 1948, 2-14; and McAlister Coleman, "A Master Talker," Nation, June 25, 1949, 714. 
As the debate passed from Progressive reformers of the 1910s to historians and political scientists in the 1960s and 1970s, the role of the boss himself became curiously diminished in historical accounts. Though Harold Zink's 1930 City Bosses in the United States attempted to discuss the personality of the boss and to muse whether or not a "typical" boss can be described, historians since Zink have placed the boss in the background in favor of political science and sociological models geared to explain the creation and remarkable durability of the machines. Model-builders have depicted the machine as everything from a despotic entity preying on immigrants as a means of preserving its conservative agenda, to a form of extralegal socialism bent on the redistribution of wealth along ethnic lines. ${ }^{9}$

Although the specific details of their proposed models vary, political scientists and sociologists have gravitated toward a focus on the tangible rewards bosses offered their followers. By ignoring the charisma of the boss as a central force in the machine's appeals to voters, scholars marginalize the role of the boss in the creation and maintenance of the machine. Though these material factors are of indisputable significance, they do not help to explain why it was Frank Hague and not another poor boy from Jersey City who was able to consolidate the power of the city (and in many cases even state and federal) government entirely within his personal control.

Historians have begun to describe the cultural role of the political rallies and street fairs, but not explicitly their significance in supporting bosses and machines. ${ }^{10}$ Though he

\footnotetext{
${ }^{9}$ See James C. Scott, "Corruption, Machine Politics and Political Change," American Political Science Review 63, no. 4 (1969): 1144; Edward C. Banfield and James Q. Wilson, City Politics (Cambridge, MA: Harvard University Press, 1965); Clifton K. Yearley, The Money Machines: The Breakdown and Reform of Governmental and Party Finance in the North, 1860-1920 (Albany: State University of New York Press, 1972); Nathan Glazer and Daniel Patrick Moynihan, Beyond the Melting Pot: The Negroes, Puerto Ricans, Jews, Italians, and Irish of New York City (Cambridge, MA: MIT Press, 1970); and Steven P. Erie, Rainbow's End: Irish-Americans and the Dilemmas of Urban Machine Politics, 1840-1985 (Berkeley: University of California Press, 1990).

${ }^{10}$ Sean Wilentz has spoken of working-class demonstrations and popular political involvement in the early republic in Chants Democratic: New York City and the Rise of the American Working Class, 1788-1850 (New York, NY: Oxford University Press, 1984), and his analysis is a helpful methodological starting ground for deciphering the symbols and meanings of group gesture and activity. Somewhat closer in focus, Michael E. McGerr, The Decline of Popular Politics: The American North (New York: Oxford University Press, 1986), discusses the political traditions of the early postbellum years that fostered the first wave of ethnic machines. McGerr has paid considerable attention to the cultural symbolism of political rallies and mass meetings. "Spectacular campaigns became a process of communal self-revelation," he has argued. "In effect, men voted twice at an election - once by casting a ballot, and once in the street by participating in campaign pageantry (37)." McGerr has argued that many elements merged to form the ecstatic partisan display of the great rallies for presidential elections: "transforming communities into partisan tableaux, spectacle fused martial dreams, intellectual endeavor, leisure enjoyment and hard labor in the service of politics (37)." Although he has spoken of national campaigns, and his is a story of waning popular involvement in national elections during the end of the nineteenth century, McGerr's analysis is helpful in deciphering the kinds of rallies and events that continued in cities as banners for national figures were replaced with local polls and the entire process focused more tightly on the metropolis. Interestingly, popular writers have paid more attention to bosses' public personas in the creation of their popular appeal, even if only to celebrate. See William V. Shannon, The American Irish: A Political and Social Portrait (New York: Collier Books, 1974); George E. Reedy, From the Ward to the White House: The Irish in American Politics (New York: Charles Scribner's Sons, 1991); and Andrew M. Greeley, The American
} 
spoke of an earlier era, Michael McGerr was particularly clear in his understanding of the complex connections between the politician and the voters played out on the buntingtrimmed stage of the political rally. "Spectacle... became an intricate dance of accommodation between the candidate and the people," 11 insisted McGerr, speaking of the political pageantry of the mid-nineteenth century, and this description applies even more strongly to the local elections for which bosses and their candidates promoted themselves. The primacy of local elections demanded significantly more visibility and availability of local politicians than it did of presidential candidates during the era of "front-porch" campaigns when candidates rarely if ever, appeared in public. The intricate dance McGerr described grows increasingly complex in the close quarters of the urban municipal setting, where politician and voter remain in close contact.

Adapting McGerr's analysis to take into account not only the spectacle but also the underlying ethical framework it represented makes it possible to understand Hague's ability to build a coalition encompassing both rank-and-file machine Democrats and Progressives by his use of the drama of street rallies and torchlight parades. To understand the development of Hague's political style it is instructive to look at the period during which that style took shape. During the early portion of his career, before he became mayor in 1917, Frank Hague honed his political showmanship. The massive parades through Journal Square during his later reign can best be understood by examining the more modest ones in Jersey City's Second Ward before the turn of the century.

Hague's early career can be divided into two phases. The period before 1908 found Hague in the role of the traditional "pol," a loyal machine worker and political ringmaster working within the ethical and cultural ideology of his immigrant ward. However, beginning after his 1908 appointment to the position of City Hall Custodian (Figure 2), and blooming fully by his 1913 support for the installation of commission government for Jersey City, Hague reinvented himself as a reformer and a Progressive, appealing to middle-class ethics favoring "good government" and a depoliticized civil service.

Insisting that Hague was not in fact a true Progressive, many scholars have suggested that he merely aped a Wilsonian agenda as a means of copying the governor's meteoric political rise. ${ }^{12}$ Others, in an attempt to rehabilitate Hague's historical image, have hailed him as a genuine reformer at least in the mid-1910s. ${ }^{13}$ In fact, Hague's Progressive turn was a series of complex cultural and political events.

Irish (New York: Harper and Row, 1981), as well as numerous popular biographies of other individual bosses.

${ }^{11}$ McGerr, Decline of Popular Politics, 30.

${ }^{12}$ Rapport, The Statesman and the Boss.

${ }^{13}$ Foster, "Frank Hague of Jersey City"; Michael T.J. MacMahon, "Frank Hague as a Humanitarian" (lecture, St Peter's College, Jersey City, NJ, February 10, 1982); John J. Corcoran Jr., "The Greatest Mayor that Ever Lived" (paper, 1981), Hague Collection. 


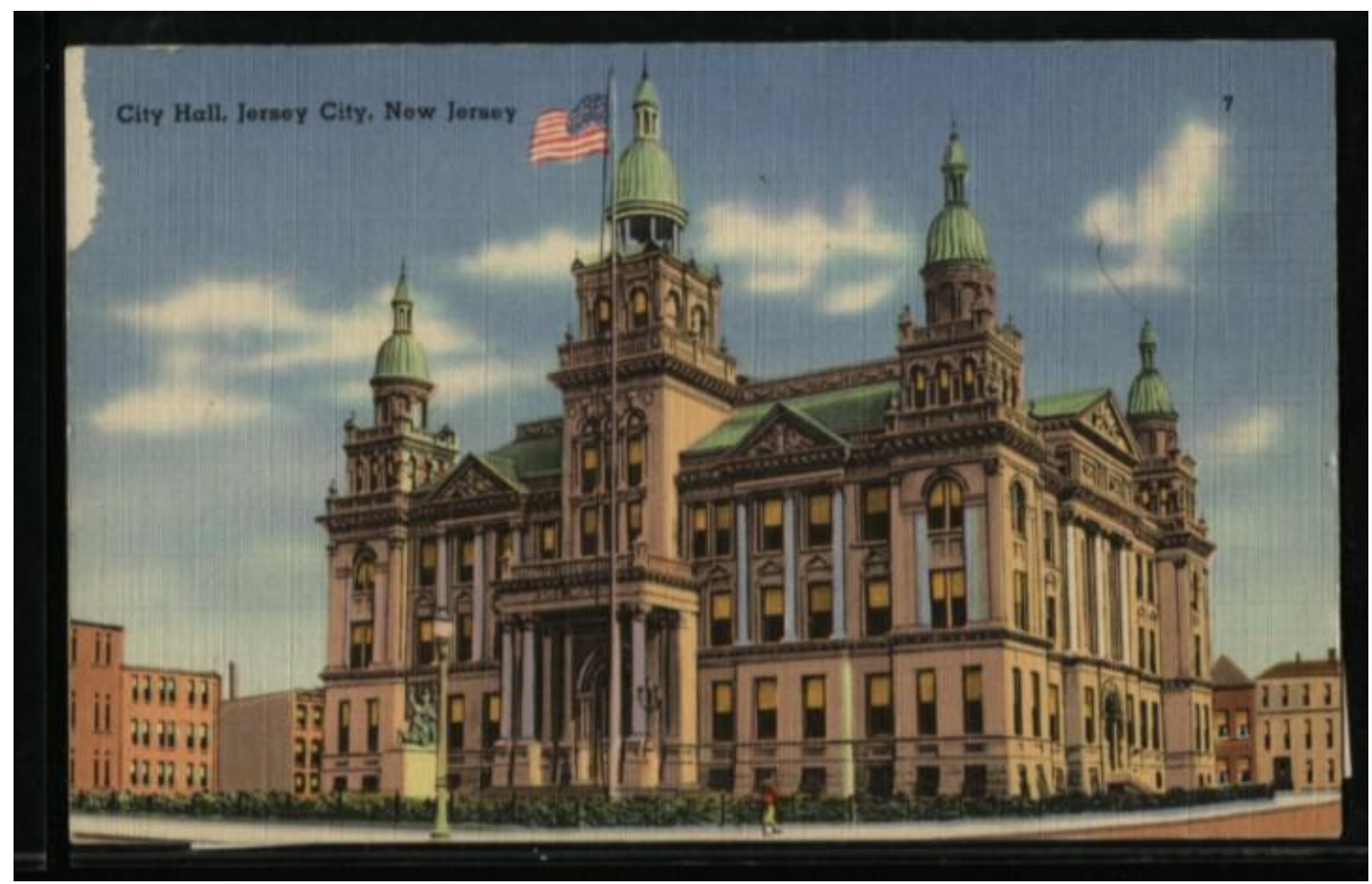

Figure 2. City Hall, Jersey City, New Jersey. Courtesy Jersey City Free Public Library

\section{Haig and the Horseshoe}

Frank Hague first began to develop his political style in the small neighborhood by Jersey City's waterfront known as the Horseshoe, a working-class enclave of Irish, German and Italian immigrants and first-generation Americans. ${ }^{14}$ Hague was the second of eight children born to John Hague, a blacksmith and security guard, and his wife Margaret. Both had come to Jersey City from County Cavan, Ireland. Growing up in the Horseshoe section where, as one contemporary journalist put it, "politics and political strife are enjoyed as much as a square meal," ${ }^{15}$ Hague embodied a political ethic built on entertainment as a key element in the politician's public appeal. Often the political content was secondary to the entertainments. As one account of a 1907 rally complained, "The shouts for this candidate or that one were so deafening that it was impossible for the dancers to keep time with the music of the orchestra." ${ }^{16}$ Later, after Hague's selfreinvention as a progressive, this entertainment-oriented political tradition remained a central part of his approach.

But "Shoe" politics were not merely a spectacle, devoid of content. Rather, the Horseshoe paraded its political ethics through the streets in election campaigns. Such slogans as “THE HORSESHOE AGAINST THE WORLD,' and 'THE HORSESHOE TAKES

\footnotetext{
${ }^{14}$ Richard J. Connors, A Cycle of Power (Metuchen, NJ: The Scarecrow Press Inc., 1971), 8-16.

15 "Hague Remains Ward Leader," Jersey Journal, February 6, 1908.

16 "Blooms Galore Sprung at Gazinck Picnic," Hudson Observer, August 8, 1907, Wittpenn Scrapbooks, Jersey City Historical Project Collection.
} 
CARE OF ITS OWN,"17 reinforced the values of loyalty and neighborhood. In contrast to reformers' demands for a depoliticized civil service where personal relationships and loyalties wouldn't sway officials in their execution of duty, Horseshoe residents expected that their political loyalty would be matched by the loyalty of their leaders - a loyalty repaid in the form of jobs and favors. Hague carefully maintained his credibility within the 'Shoe's value structure while he simultaneously made an appeal to the reformers' sensibilities.

Little concrete information on Hague's early years survives, and much that is available bears the scars of the ideological and political agendas of its authors. J. Owen Grundy complained that most of the major work on Hague has been "journalistic and sketchy,"18 an observation that seems especially true for his earliest years. Both Hague apologists and those attacking his record have made much of Hague's impoverished childhood.

Supporters have described Hague's early travails much like a Horatio Alger tale; writers such as McKean have used it to psychologize Hague and to explain the "sinister" elements of his personality. In a 1940 exposé, Saturday Evening Post was even more blunt, describing Hague as a "mug" and beginning its article by pointing out that Hague had been "expelled from sixth grade as a truant and a dullard." ${ }^{19}$ Hague himself took an active part in mythologizing his youth, and, as McKean has noted, "A favorite theme for speeches to political audiences is to recount in detail the story of his rise... he frequently alludes to his wild youth and to the narrowness of the margin by which he escaped being led into a life of crime." 20

Whatever Hague's specific psychological baggage, his childhood was a training ground for his later political career. While McKean attributes Hague's political savvy to "that political sense that his nationality seems generally to possess," ${ }^{21}$ it seems clear that he learned it on the streets and in the saloons of Jersey City's Horseshoe neighborhood during his youth. His scholastic career ended in 1889 when he was dismissed from school as incorrigible, after less than a sixth-grade education. ${ }^{22}$ With newfound time to spend with political notables in Horseshoe saloons, Hague's political education was underway.

The political life of the Horseshoe during the late nineteenth century took place in saloons, and the tiny neighborhood boasted forty of them during Hague's youth. Though a lifelong nondrinker, Hague frequented saloons in his youth as a means of keeping up on the political news of the neighborhood. ${ }^{23}$ Although only one source links Hague with a specific gang, ${ }^{24}$ two of his older brothers were members of the "Red Tigers." ${ }^{25}$ Hague,

\footnotetext{
${ }^{17}$ Frank Hague Eggers Jr. quoted in Bob Leach The Home Ground 2, (1996), Jersey City Historical Project.

${ }^{18}$ J. Owen Grundy, President, Hudson County Historical Society, Jersey City, NJ to Richard J. Connors, Assistant Professor, Seton Hall University, February 17, 1965, Hague Collection.

${ }^{19}$ Jack Alexander, “King Hanky-Panky of Jersey," Saturday Evening Post, October 26, 1940, 9-11, 119-24.

${ }^{20}$ McKean, The Boss, 6-7.

${ }^{21}$ Ibid., 15.

${ }^{22}$ Tumulty, "Frank Hague," 2; McKean, The Boss, 25.

${ }^{23}$ Tumulty, "Frank Hague," 2.

${ }^{24}$ George Biehl to Lester H. Clee, Speaker of New Jersey Assembly, and Sidney Goldberg, member of House Committee on Elections, February 1, 1935, Jersey City Historical Project Collection.

${ }^{25}$ McKean, The Boss, 20.
} 
who was large and athletic, received some of his earliest political jobs as a poll-side tough, placed strategically to "encourage" voters to favor a specific candidate in the days before secret balloting. Hague's "considerable skill as a boxer" ${ }^{26}$ made him attractive to local political figures, who began to take note of the flashily dressed teenager.

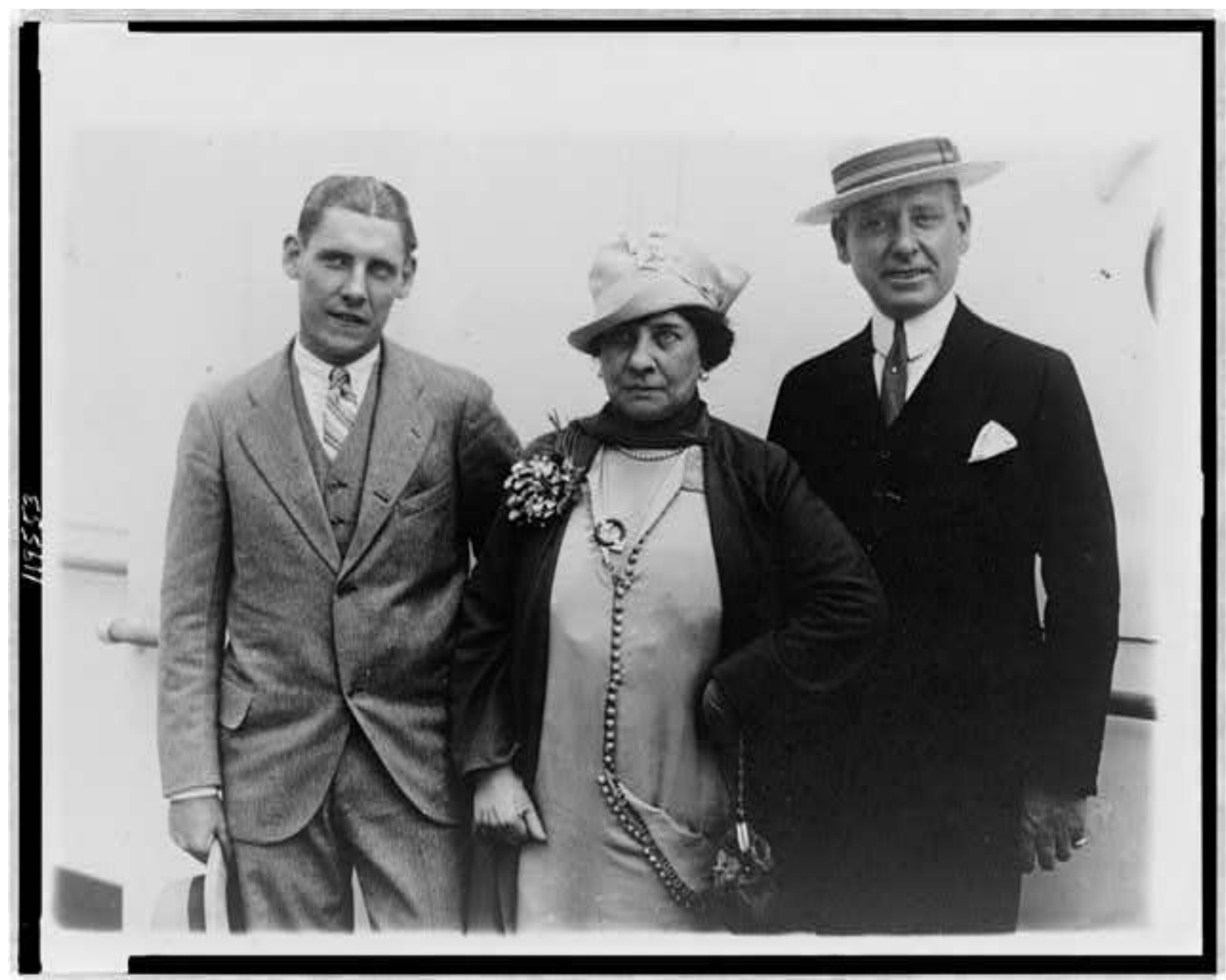

Figure 3: Frank Hague, his wife, and son, Frank, Jr., 1925. Reproduction Number: LC-USZ62-119553. Library of Congress Prints and Photographs Division Washington, D.C.

In a political culture defined by dramatic public presentations, young Frank Hague became a notable figure. His size and bearing made him a natural standout; his hightoned fashion made him more so. Even before his political career began in earnest, he was known around the neighborhood. Hague's dramatic dress - which stayed with him throughout his life - may not have been, for him, solely a tool of self-promotion. It is clear that he was intent on building a public name to help achieve his political aspirations, and his sartorial style helped mark him as a "sharp" (Figure 3). ${ }^{27}$

\footnotetext{
${ }^{26}$ Ibid., 27

${ }^{27}$ Leach, Frank Hague Picture Book, $2,4$.
} 


\section{Constable Hague}

Frank Hague's political career began in 1896 when local saloon keeper Nat Kenny chose him as a candidate for constable. Kenny began struggling for power in the Horseshoe with the aging boss of Hudson County, Dennis "Denny the Mick" McLaughlin, and his young protégé, Bob Davis. To punish the upstart Kenny, McLaughlin opened the Park House, a lavish saloon down the street from Kenny's own tavern and political headquarters. The rivalry continued, and eventually the torchlight parades sponsored by each saloonkeeper to drum up business grew violent. Davis, now the acting boss, stepped in to try to halt the feud between McLaughlin and Kenny. As a peacekeeping symbol, Davis sought to persuade the two warring parties to agree on a ticket for the upcoming constabulary elections. Davis's peacekeeping mission failed, however. Kenny staked Hague with seventy-five dollars with which to "make friends" 28 and installed the twentyone-year-old as candidate for constable, over the objections of Davis and his machine. ${ }^{29}$

Hague made the most of this opportunity by building a coalition of support ranging from local bookie Charles "Goodey" Goode to local clergyman Monsignor Sheppard, both of whom remained Hague supporters for years. ${ }^{30}$ Thus, from his first election, Hague sought and received support from both the visible and invisible power bases in the community. Hague attacked the character of Davis's and McLaughlin's candidate in the primary, a local tough named "King" Callahan, ${ }^{31}$ and quickly drew support to his own candidacy.

Once he beat Callahan, Hague's success in the general election was assured, and he defeated the Republican opposition soundly. Hague moved to make himself appear a natural leader and began hosting political events in support of party candidates. ${ }^{32}$ The unpaid constable position held many advantages for the ambitious Hague. His duty as a poll-watcher on election day made him particularly useful to party officials who wanted events to run smoothly at the ballot box. His responsibility to escort prisoners to the penitentiary at Trenton presented an opportunity to cement friendships and to prove his largess by providing a final pre-prison supper for his felonious friends. ${ }^{33}$

Hague's resistance to the constable's uniform, which reportedly resembled that of a trolley conductor, offers a significant insight into his early image-building. ${ }^{34} \mathrm{He}$ eschewed the uniform whenever possible in order to maintain his developing image as a leader.

Taking note of Hague's following and growing numbers of favorable press clippings, Davis moved to bring him into the machine's fold. Although nominally an anti-machine candidate backed by Kenny, not Davis, Constable Hague found himself at home in the

\footnotetext{
${ }^{28}$ McKean, The Boss, 29.

${ }^{29}$ Leach, "The War of the Beer Barrels" (unpublished manuscript), Jersey City Historical Project

Collection; Foster "Frank Hague of Jersey City," 8; McKean, The Boss, 27-30

${ }^{30}$ Leach, "War of the Beer Barrels," 5.

${ }^{31}$ Ibid., 4.

${ }^{32}$ Foster, "Frank Hague of Jersey City," 9.

${ }^{33}$ Leach, "War of the Beer Barrels," 5.

${ }^{34}$ Ibid.
} 
political climate around him. Little separated him from the other members of Davis's machine, apart from his aggressiveness and energy. At this stage in his career, Hague was the classic machine pol, solidifying his position as the man to see about a job or problem with the police. His efficient work as constable and as one of Davis's key men in the district earned Hague an appointment as deputy sheriff two years later.

Hague received his first major political setback in late 1904, when he became caught between two competing loyalties. Thomas "Red" Dugan, a local Horseshoe ne'er-do-well and Hague childhood friend, was arrested for forgery in Boston. Deputy Sheriff Hague was subpoenaed to appear in court in New Jersey on the day of Dugan's trial in Boston. In a legendary impassioned plea, Dugan's mother prevailed upon Hague to go to Boston, where he testified that, although he could not be certain, he believed he had seen Dugan in a park in Jersey City on the day of the crime. ${ }^{35}$

At first, Hague's trip to Boston remained a secret, and only his failure to appear in court in Jersey was noted in an article buried ten pages into the Hudson Dispatch. ${ }^{36}$ The

Dispatch's piece was enough to cause problems, however, and two weeks later the Jersey Journal reported that Hague had been fined one hundred dollars and dismissed from the constabulary. ${ }^{37}$

Although the scandal forced Davis to dismiss Hague from his position as ward leader, Hague's credibility within the Horseshoe was high. According to Robert Leach, Hague had "gained the everlasting respect of many residents in the Shoe. Here was a man who would stand up for one of his own." 38

Rather than burying the scandal, Hague reveled in it. Dugan's mother, whose tearful entreaty had convinced Hague that his duty to a friend outweighed his duty to the court, routinely appeared by Hague's side at campaign rallies. ${ }^{39}$ Hague's trip to Boston was within the ethical order of the ward that in Hague's youth had proclaimed loudly, "THE HORSESHOE TAKES CARE OF ITS OWN." "I0 It was not until 1911, after Hague had begun to remake himself into a Progressive, that the Red Dugan incident would become a significant liability.

The following year, Davis rewarded Hague with a position on the county's Democratic nominating committee, thus placing Hague among the elite power brokers in Hudson County. Hague also sought and won re-election as constable. ${ }^{41}$ By 1907 , Hague, now sergeant-at-arms for the state Assembly, had returned as leader of the second ward. ${ }^{42}$

35 “Wittpenn Admits Hague went to Boston on Behalf of 'Red' Dugan,” Jersey Journal, October 211911 ; Leach, The Horseshoe Lad, Jersey City Historical Project, 1996.

36 “Hague Did Not Obey Grand Jury Subpoena," Hudson Dispatch, October 10, 1904.

37 "Hague Guilty of Contempt of Court," Jersey Journal, November 10, 1904.

${ }^{38}$ Foster, "Early Career," 19.

${ }^{39}$ Leach, "Home Ground," 13.

${ }^{40}$ Ibid., 5.

${ }^{41}$ Foster, "Early Career," 19.

42 Ibid., 20. 
By 1908, however, Hague was caught between two warring factions in the Democratic machine. Hague backed Otto H. Wittpenn (Figure 4) for mayor, despite Davis's ambivalence. After Wittpenn's election, Hague's efforts were rewarded with the position of chief custodian of city hall over the objections of Davis who had another candidate in mind for the position (which paid a sizeable two thousand dollars a year). As custodian, Hague had the authority to hire the sizable maintenance staff for city hall, thus affording him new opportunities to dole out patronage jobs. It also gave him a front-row seat in city hall to all of the political goings-on.

Hague's new position increased both the cash in his pocket and the patronage at his disposal, but he found himself in the midst of the ensuing feud between Kenny and the new mayor. In an attempt to retain his alliance with both men, Hague claimed fealty to all sides: "I shall be loyal to Robert Davis", he insisted in an interview with the Jersey Journal; "I shall gladly fight under Davis's leadership and of course I shall never forget the obligations I am under to mayor Wittpenn, whose firm friend I shall continue to be."43 His attempt was unsuccessful, and after a bitter ward fight, Davis disciplined Hague by removing him from his position as ward leader once again.

"Friendship" and "obligation," both central tenets of the machine ethical order, became increasingly problematic for Hague as custodian. Once within city hall, Hague began to remake himself from constituent-minded ward pol to civic-minded city employee. Just as he began to promote himself as a reformer in favor of "good government," he came under fire from Davis and those back home in the "Shoe. During the fight in which he lost control of the Second Ward Tammany Club, Davis's men accused Hague of not living up to his ethical duties to support his followers. Peter P. Murphy, one of the Democratic faithful, accused Hague of forgetting his roots and first loyalties: "He has not stood well with the Irish-Americans," Murphy insisted. ${ }^{44}$

The Hudson Observer made a similar claim, suggesting that Hague "has not looked out for men in the Second Ward when it came time for the distribution of "plums' ... but instead for his own interests." 45 Although the specifics of the claim, coming as they did from Davis supporters, may have been more political rhetoric than genuine complaint, the form such attacks took is significant. Detractors challenged Hague's loyalty to his supporters and claimed he was selfish - unforgivable sins in the 'Shoe.

The custodianship of city hall would seem to have been a far more valuable job in terms of patronage dispensation than in terms of potential publicity, but Frank Hague found a way to get both from his new job. In addition to the nearly one hundred positions on the city payroll now at his disposal, Hague drew plaudits for his energetic attention to his duties. Within two weeks of his installation on January 1, 1908, local papers praised the cleanliness of the city hall under Hague's supervision. ${ }^{46}$ This reputation for diligence would prove a critical building block for his later reinvention as a crusading Progressive,

\footnotetext{
43 Jersey Journal, March 7, 1908, quoted in Foster, “Early Career," 17.

44 “Mix-up in Horseshoe over Hague," Jersey Journal, June 2, 1908.

45 "Fight Against Hague Bitter"” Hudson Observer, February 5, 1908.

46 "Hague Transforming the Big City Hall," Hudson Observer, January 9, 1908.
} 
and would distance him further from the older ethical order of "Red" Dugan and company.

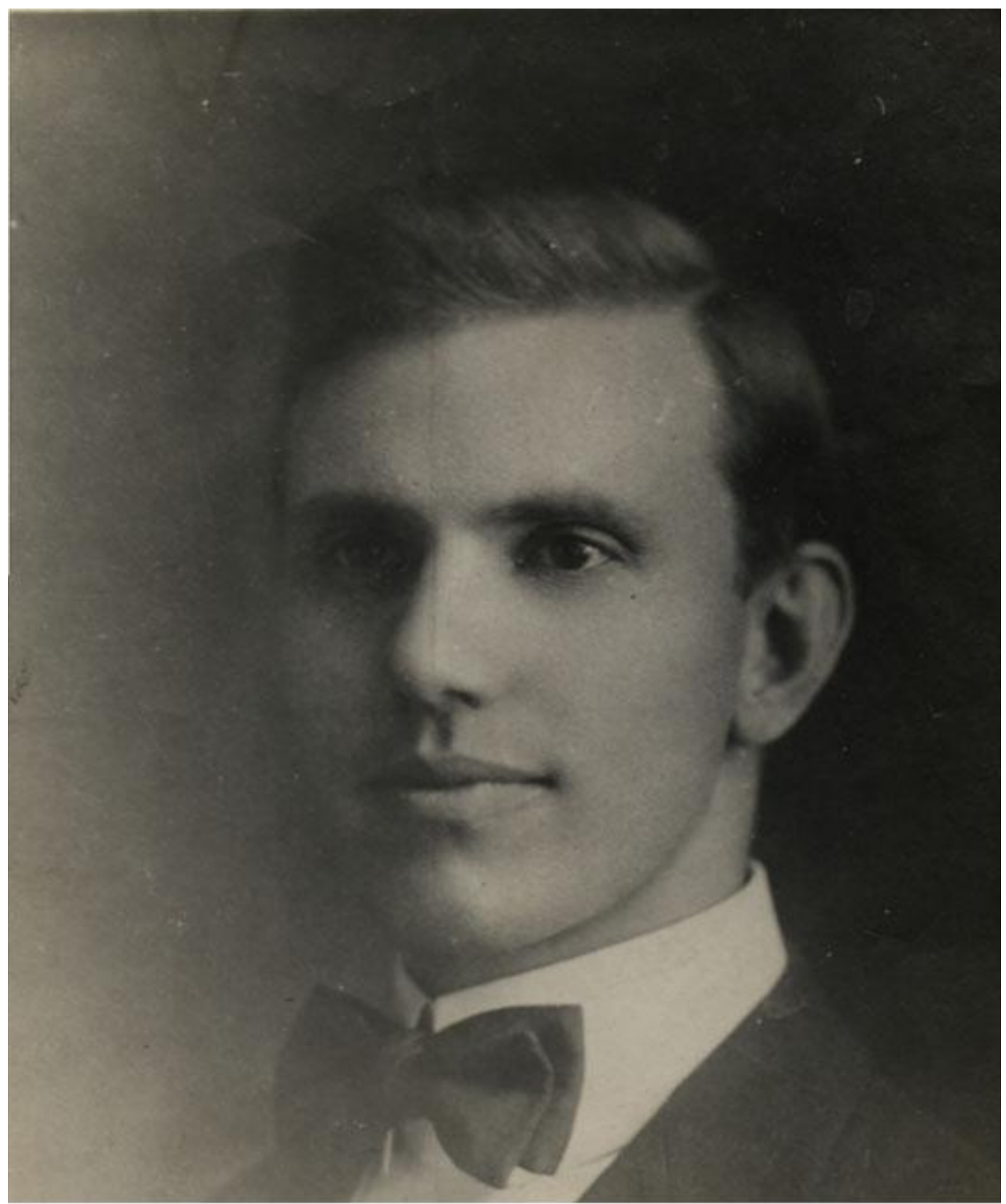

Figure 4. H. Otto Wittpenn, circa 1907. Courtesy Jersey City Free Public Library.

Hague began to take on reform causes beyond his specific duties at city hall. He spoke against the use of dirty-burning "soft coal" by the railroads whose tracks crisscrossed the Horseshoe (Figure 5). ${ }^{47}$ While Hague remained focused primarily on the Horseshoe and its residents, he expanded his crusading to encompass all of Jersey City.

47 “Mayor Will Attend Soft Coal Meeting," Hudson Observer, May 13, 1908. 
Hague's transformation into responsible civil servant was far from complete, however, as an altercation between Hague and a co-worker illustrates: "before the row was over," the Jersey Journal observed, "Hague had landed his fist in Hart's face, and the war of words had attracted a crowd." 48 If Hague took a lesson from this incident, it was that the war of words had attracted the attention.

From 1908 forward, Hague took an aggressive position in conflicts with other leaders. Davis attempted to discipline both Hague and Wittpenn by removing Hague as ward leader and derided Hague's work at city hall, but Hague was not cowed by the county leader. Instead, he used the press both to assert his independence and to support his record. "The fact is that since I became City Hall Custodian under Mayor Wittpenn on Jan. 1, I have been complimented repeatedly on the way I am keeping City Hall in order," he told the Jersey Journal. "I am going to go right on doing my duty. Davis's attack will not deter me." ${ }^{49}$

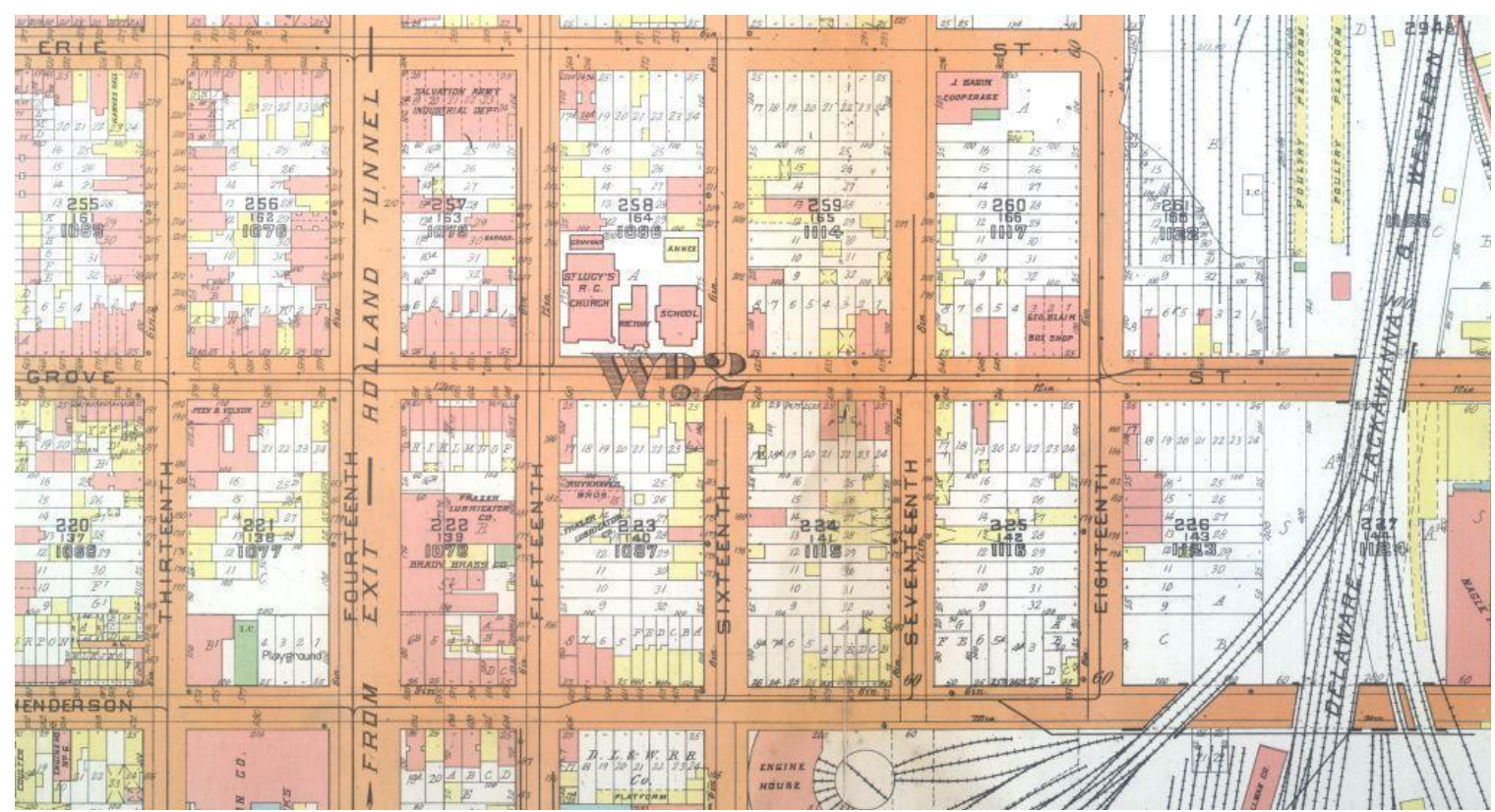

Figure 5. Jersey City's Second Ward (detail). Plate 12 from the Plat book of Jersey City 1928. Source:

Rutgers University Special Collections and University Archives.

Although Davis was still too powerful to attack directly, Hague showed little restraint in assailing Davis's choice for his replacement as ward leader, John Sheehy. Hague taunted Sheehy publicly, asking, "Has all the fight in Sheehy gone out of him? I hoped for real excitement.... We would have made this ante-primary fight one of the most interesting in Jersey City's history." ${ }^{, 50}$ Significantly, Hague promised the 'Shoe residents first and foremost a good show, and as Sheehy supporter James Hennessy complained, "Hague is

\footnotetext{
48 "Custodian Hague in Fight with Hart," Jersey Journal, February 2, 1908.

49 "Hague's Friends Go for Davis," Jersey Journal, June 1, 1908.

50 "Hague to Sheehy, 'Oh, do arrest me!"” Article from unidentified newspaper clipping, November 24, 1908, Wittpenn campaign scrapbooks, Jersey City Historical Project Collection.
} 
playing to the galleries." ${ }^{, 51}$ As Hague was fast learning, these galleries were his key to success.

Once Sheehy finally secured control of the Tammany Club, Hague's response was to splinter its membership by forming a separate organization, the "Tammanee Club,",52 thereby prolonging the fight off and on for several years. Hague held onto the city hall position but lost control of the ward. In addition to his fight with Sheehy, a rift developed between Wittpenn and Hague in 1911. After Davis's death that year, Jersey City Democrats found themselves in disarray. Hague coveted Davis's position as city collector, but, in order to promote unity, Wittpenn installed one of Davis's former lieutenants. ${ }^{53}$

\section{Progressive Agenda/Personal Politics}

Hague's repackaging of himself as a Progressive was far from complete by 1911. He came out strongly against commission government and against Wittpenn in that year's mayoral election. ${ }^{54}$ The Walsh Act of 1911 permitted a municipality to hold a referendum to reorganize its government into a small but powerful board of commissioners, each responsible for a specific aspect of city government. ${ }^{55}$ Progressive-minded middle-class observers such as the editors of the Jersey Journal saw commission government as a way of breaking the electoral power of ethnic ward leaders. Beyond its tactical political value, the rationalization of government under commissioners with precisely defined responsibilities came to be seen as a panacea for all of the city's ills. ${ }^{56}$ Although Hague returned to the fold in time for the mayoral election, securing Wittpenn's support for his run for a seat on the street and water board, it was only after the talk of commission government had been silenced. ${ }^{57}$

Hague's first citywide election was a hard fight. A different set of political rules applied in the larger arena, rules Hague was still learning. On October 12, 1911 the "Red" Dugan incident returned to plague him when George L. Record, a crusading Republican, attacked Hague, and by association Wittpenn, in a speech revisiting all the details of Hague's 1904 trip to Boston. This time, Hague could not turn a scandal into political capital. As a candidate for the street and water board, arguing in his own speeches for a Progressive agenda, Hague had to play to a wider audience than the Horseshoe faithful, an audience less likely to be moved by the tears of Dugan's mother.

Record's nightly attacks continued in speeches throughout Jersey City, and, unlike 1904, the public did not seem to tire of the issue. Dugan's trial, and Hague's role in it, captured

\footnotetext{
51 "Hague Asks Hennessy for an Accounting," Jersey Journal, October 20, 1908.

${ }^{52}$ Foster, "Early Career," 36.

53 "Say Hague is Not Collector," Jersey Journal, January 25, 1911.

54 “Wittpenn Fires Boards After Frank Hague," Jersey Journal, July 20, 1911.

${ }^{55}$ Connors, Cycle of Power, 16-17.

${ }^{56}$ Editorial, Jersey Journal, November 11, 1912.

57 "Frank Hague is back with Wittpenn," Jersey Journal, August 23, 1911; "Sad Sea Waves Said Harmony to Me, Says Hague," Jersey Journal, October 3, 1911.
} 
considerably more newspaper ink in 1911 that it had in 1904 - with no new information coming to light. By his own admission, Record had cribbed his speeches from the 1904 Journal articles, which the paper reprinted alongside the new coverage. The Journal went so far as to send a reporter to Boston to try to obtain a transcript of Hague's testimony. ${ }^{58}$

Hague eventually prevailed in the election, but "Red" Dugan remained a political liability for Hague outside the Horseshoe for the remainder of his pre-mayoral career. In addition to the return of Dugan, charges of previous election irregularities plagued Hague. ${ }^{59}$ Although he was eventually cleared, the scandal further damaged his growing image as a Progressive candidate.

In the midst of the scandals, Hague tried to outline his new Progressive agenda. Replying to an open letter to candidates by the Eight Ward Civic League, an "improvers" group, Hague insisted, "The Street and Water Board needs Progressive men, men whose backbones are not of the jelly-fish order, men who will fight the people's fight." ${ }^{60}$ If Jersey City residents remained skeptical about Hague's transformation, they at least offered him the opportunity to prove himself by electing him to the board. Even if they had shown him support in the election, however, Hague had yet to convince Jersey City's Progressives that he was one of their own. Referring to the condition of the streets, George Prigge of the Twelfth Ward Improvement Association warned, "It is up to Mr. Hague to prove that he intends to make some moves on the matter." 61 Hague moved quickly and publicly to live up to Prigge's hopes.

Hague racked up column inches in the Jersey Journal after winning his place on the street and water board and remodeling what had been a sleepy post into a headline generator, much as he had done as custodian. Four days after taking office, Hague, the junior member of the five-man board, went to the press with a communication he had sent to Police Chief Monahan demanding improved police enforcement of litter laws. ${ }^{62}$

No matter how theoretical the issue, Hague found a way to make it personal: litter wasn't the problem; Monahan was. Similarly, when Hague and the rest of the board argued over the details of a deal to supply water to neighboring Bayonne, Hague attacked Wittpenn by dramatizing meetings as scenarios where he stood bravely alone against four Wittpenn lackeys. ${ }^{63}$ When Wittpenn attacked Hague, he did not do so on his failings as a reformer; instead, the mayor took Hague to task for his lack of loyalty and discipline to the party machine. At one meeting a Wittpennite accused Hague of having "'thrown down' the Mayor after receiving favors from him."64 This time, the rift between Hague and

\footnotetext{
58 “Won't Give Out Hague's Testimony,” Jersey Journal, October 25, 1911.

59 "Hague is Accused by Election Bd.," Jersey Journal, September 18, 1911.

60 "Prout and Hague Answers to Improvers," Jersey Journal, October 20, 1911.

61 "Improvers Put It to Hague," Jersey Journal, January 11, 1912.

62 "Hague Says He Intends to Have Clean Streets," Jersey Journal, January 4, 1912.

63 "Hague Single Handed, Tackles 'Water Snake," Jersey Journal, January 24, 1912, 1-2; "Ready to Fight Mayor if Need Be, Says Hague,” Jersey Journal, February 2, 1912.

64 “Lambastes Hague at Wittpenn Club Fest,” Jersey Journal, May 3, 1912.
} 
Wittpenn proved permanent. The "Water Snake," as the press dubbed the Bayonne water scandal, proved the breaking point in the Hague-Wittpenn alliance. ${ }^{65}$

Hague enhanced both his Progressive image and his public visibility by using the Water Snake to demand that all city board meetings should be made public on the grounds that doing so would afford a higher level of accountability for city officials. ${ }^{66}$ Not only did this demand for transparency in the workings of government mirror Progressive demands; it also afforded Hague a wider stage for his own use. On occasions where he could not secure a public meeting, Hague simply reiterated its content to the press. Hague's demand for public accountability and his attack of the Bayonne water deal had considerable effect; even the Republicans grudgingly praised him. ${ }^{67}$

Hague also began to focus publicly on women and protection of the family, a position that had cross-class appeal. Speeches to women's clubs became a regular event during his time on the board, and the protection of women and families became a common trope in his public appearances. ${ }^{68}$

While incorporating the middle-class' Progressive agenda, Hague did not distance himself from his own class and ethnic origins. Instead, he built his poor and troubled childhood into a narrative of self-uplift that read both as a celebration of his origins and a celebration of his new identity as respected civil servant. A writer for the Jersey Journal summarized Hague's public presentation of himself as he reported on a speech Hague gave before the Salvation Army on "The Uplift of Mankind." "To cultivate a strong willpower was the essential thing to success, Mr. Hague said and he set himself up as a model of a man who, although beset on every side by difficulties in his climb up the latter, was urged on to greater things, even by defeat." ${ }^{69}$ Similarly, his devout Catholicism helped appeal to both groups. His devotion to the Catholic Church illustrated to his old constituents that he remained one of them. Although the middle class might have preferred Methodism, it could find no fault with the seriousness with which Hague professed his faith.

Hague remained a political innovator. Even within the rubric of entertainment politics, he sought new ways to appeal to voters. He began increasing the draw to his rallies by showing outdoor movies. ${ }^{70}$ By incorporating the new technology into the older system of politicking, Hague ensure that his rallies remained fresh and exciting in comparison to others in the Horseshoe.

\section{Frank Hague vs. Woodrow Wilson}

\footnotetext{
65 "Hague, Single Handed, Tackles 'Water Snake.",

66 "No Secret Sessions for Hague,” Jersey Journal, January 25, 1912.

67 "Republicans Almost Endorse Frank Hague," Jersey Journal, January 30, 1912.

68 "Hague Talks to Women About Dirty Streets," Jersey Journal, February 27, 1912; "Hague Hampered by 'Old and Incompetent Men,'” Jersey Journal, February 28, 1912.

69 “Frank Hague S.A. Speaker,” Jersey Journal, March 19, 1913.

${ }^{70}$ Foster, "Early Career"” 50.
} 
From the Progressive point of view, Hague took a serious misstep in April of 1912, when he backed Essex County boss James T. Smith in the latter's effort to block the presidential nomination of Governor Woodrow Wilson. Rejoining the Davis machine, Hague attacked Wilson for disloyalty to the Democratic Party and for failure to look after the interests of Hudson County Democrats. ${ }^{71}$ Wittpenn, who hoped that a Wilson presidency would promote his own gubernatorial hopes, accused Hague of becoming a tool of the neighboring Essex County machine. ${ }^{72}$ In retribution for his disloyalty, the city payroll began to hemorrhage Hague's friends, including his brother. ${ }^{73}$

Hague fought hard against Wilson. In an ugly dispute at the state nominating committee, each side accused the other of double-dealing and fraud. By the end of the convention, Wilson had received the support of New Jersey's delegates to the national convention over Hague's strenuous objections. Even though he reversed himself and supported Wilson in the national election, Hague had made a powerful permanent enemy in Wilson and had again damaged his public image as a Progressive. ${ }^{74}$

Hague battled the political damage to his Progressive credentials from his anti-Wilson activities as he had the return of the "Red" Dugan fiasco - by redoubling his Progressive activities. After a year on the street and water board, Hague announced himself as a true Progressive. He insisted that his fights with Wittpenn and his cronies on the board had convinced him to support a change to commission government. ${ }^{75}$ The Jersey Journal, traditionally hostile to him, reversed itself and celebrated Hague's "conversion." 76

Hague took an increasingly active hand in his media portrayal. He often guided the text of newspaper accounts by sending open letters to the paper. During the campaigning for commission government in 1913, the Hague campaign committee delivered the press releases directly to the papers. Disturbed by the vilification he suffered at the hands of the editor of the Hudson Observer, Hague purchased ads in the paper calling for "fair play and [a] square deal," and supplied side-by-side comparisons between the Observer's and the Journal's campaign coverage. ${ }^{77}$

Assertions of his own independent-minded manhood - and accusations of others' cowardice - abounded in Hague's rhetoric. "I wear no man's collar. I think and act for myself, in accordance with the wishes of the people," insisted Hague. ${ }^{78}$ He responded to Wittpenn's vague accusations by challenging the mayor to a public debate:

\footnotetext{
${ }^{71}$ Rapport, The Statesman and the Boss, 131-43.

72 "Wittpenn Men Slam Hague and Jas. Smith, Jr.," Jersey Journal, March 15, 1912.

73 "Frank Hague's Brother Is Dismissed," Jersey Journal, April 13, 1912; "Hamill Lined Up with Wittpenn against Hague," Jersey Journal, April 17, 1912; “Hague Says He Is Not Boss," Jersey Journal, April 18, 1912; “Another Hague Man will be Bounced," Jersey Journal, April 25, 1912.

${ }^{74}$ Foster, "Early Career," 68-72.

75 “Frank Hague Tells Why He Is for Commission Government," Jersey Journal, December 31, 1912.

76 “Mr. Hague's Conversion,” Jersey Journal, January 14, 1913.

77 "Frank Hague Asks for Fair Play and Square Deal" (advertisement), Hudson Observer, June 6, 1913.

78 “Hague Tells Why He Split with Wittpenn,” Jersey Journal, May 12, 1913.
} 
He is cowardly to run away and refuse to face the test after he has in one of his little ward club meetings where he was among friends and he knew that his remarks would be published in the newspapers and reach a larger audience, made the assertion that he would tell something on me that would silence me. I have dared him to meet me before all the people who can be crowded into the large auditorium of the High School and there tell the thing which he says will put me out of business as a candidate. He is a coward to be afraid to face me and say it to my face and he is not a good citizen if he knows anything to my discredit and fails to make it public for the information of the voters. ${ }^{79}$

The more he transformed himself into a political brawler, the more Hague tapped into a key source of pride for the Irish community. Hague turned the amateur boxing of his youth into political sparring against his opponents, with increasing viciousness. At times Hague's challenges seemed to echo world heavyweight champion and Irish-American folk hero John L. Sullivan's famous bray, "I'll lick any son of a bitch alive!" 80 In one such instance, Hague promised to take on the entire Wittpenn administration in debate: "I don't blame the Mayor for wanting to beat me; he is afraid I will expose his schemes against the people... Let me tell you Hague will not be beaten. I invite the opposition of the Mayor and the members of his administration who follow him blindly." 81

Hague continued to hammer at Wittpenn's manhood by deriding the way he campaigned: "If he proposes to resort to the desperate tactics which he is accustomed to [sic] and trying to injure me by vague innuendoes and dastardly insinuations not based upon facts, which has been his method of fighting in the past, the people will understand why he is too cowardly to meet me in a public debate in which I have everything and he nothing to lose. ${ }^{\prime 82}$ With one comment, Wittpenn found his character attacked in the framework of both classes' ethical structures. Calling Wittpenn a coward struck at the very heart of the value system of ethnic neighborhoods like the "Shoe. However, the assertion of "vague innuendoes and dastardly insinuations" spoke to a middle class for whom character was critical. $^{83}$

The new Progressive Hague may have changed his rhetoric, but he had not changed his rhetorical style. As the 1913 commission government campaign thrust him into the foreground both within the Horseshoe and without, Hague honed his knack for vicious

\footnotetext{
79 “Mayor Afraid to Meet Me, Says Hague," Jersey Journal, June 3, 1912.

${ }^{80}$ See Dennis P. Ryan, Beyond the Ballot Box: A Social History of the Boston Irish, 1845-1917 (Rutherford, NJ: Fairleigh Dickinson University Press, 1983), 116. Also see Elliot Gorn, The Manly Art (Ithaca, NY: Cornell University Press, 1986), for a detailed discussion of the links between ethnic pride and boxing in late-nineteenth-century America.

81 "Hague Tells Why He Split with Wittpenn."

82 "Mayor Afraid to Meet Me, Says Hague."

${ }^{83}$ Warren I. Susman, Culture as History (New York: Pantheon, 1985), has described a shift in the early years of the twentieth century from a culture of "character" to one focused on the more external "personality." Although he has not described how this transition took place along ethnic lines, his analysis is critical to my conception of Hague's multi-valenced appeal. See also a similar treatment of Boston's Martin Lomasney in Matthew Raffety, "Popular Culture and a Political Boss" (Bachelor's thesis, Williams College, 1994).
} 
attack. The Jersey Journal cited one old-time Horseshoe resident who said the 1913 campaign for commission government "looked like old times." 84

Even Hague's grammar illustrates his complicated cross-class identification by combining the erudite vocabulary of the middle class with the rough linguistic edges of his working-class origins. According to McKean, "His speech is curious. He pronounces words correctly and uses them fluently and accurately - in his ambitious youth he took lessons in public speaking - but the plural form of verbs hardly exists for him."

Not all observers were as enamored with the new Hague as the Jersey Journal. The Hudson Observer warned of "schemes that lurk in commission government" 86 and suggested that his push for commission government was little more than a grasp for power, not the outgrowth of a reformist impulse. The Observer became more stridently anti-Hague as the election approached. In the midst of the paper's election eve editorial, the editors asserted - in boldface and all capitals - that "THOUGHTFUL VOTERS WILL EXCLUDE HAGUE FROM CONSIDERATION. HE IS A NOISY SHIFTY PARTISAN WHO HAS GONE THROUGH THE CAMPAIGN FALSIFYING RECORDS AND VILIFYING MUCH BETTER MEN THAN HIMSELF." $" 87$

But was the Observer right about Hague's dark intentions? If Hague was not a true convert to Progressivism, he was certainly active in support of his new agenda and spoke out against many of the Progressives' favorite targets. In 1967, historian Mark Foster pointed out that between 1913 and 1917 Hague "attacked, among other things, railroads; the insurance trust; food retailers; the local gas, water and streetcar companies; building contractors; movie theaters; houses of prostitution; narcotics and war profiteering." 88 Both Foster and George Rapport have argued that Hague learned a political lesson from Wilson's success and repackaged himself as a Progressive by 1913. Although Foster was less sure, Rapport insisted that Hague simply co-opted Progressive language for his own political glory. ${ }^{89}$ Whether he truly had Progressivism in his heart or not, Hague's shift from pol to Progressive marked a new direction for his political persona. ${ }^{90}$

Significantly, opponents of Hague felt it necessary to attack him as a campaigner as well as a candidate. The Hudson Observer published several derisive articles ridiculing Hague's ability to draw and keep a crowd. ${ }^{91}$ In one attack the Observer noted, "Numbers

\footnotetext{
84 “Hot Political Night in the Horseshoe," Jersey Journal, June 4, 1913.

${ }^{85}$ Clinton W. Gilbert, "Hague Will Rule Jersey City But 'Sticks' Balk Ambition,” New York Post, October $23,1925$.

86 "Opposition Arises in Four Cities to Four Year Terms," Hudson Observer, April 7, 1913.

87 “Jersey City’s Ten Nominees," Hudson Observer, June 7, 1913.

${ }^{88}$ Foster, "Early Career," 74.

${ }^{89}$ Rapport, The Statesman and the Boss, 100.

${ }^{90}$ Indeed, even the hearts of middle-class Progressives have been called into question by scholars. Samuel P. Hayes, in "The Politics of Reform in Municipal Government in the Progressive Era," Pacific Northwest Quarterly 55, no. 3 (1964): 162, has argued that the "ideology" of urban Progressivism was often little more than a middle-class attempt to reclaim civic power from the ethnic working class.

${ }^{91}$ See especially "Hague Has Walsh Act Meeting, But a Very Frosty One," Hudson Observer, April 8, 1913; "Audience Leaves When Hague Puts in an Appearance," Hudson Observer, April 9, 1913;

“Commission League Has Small Rallies," Hudson Observer, May 6, 1913.
} 
of people took one look at Hague and, with heads bowed, silently walked away... The throng of listeners, all of them perfectly respectable and law abiding citizens, melted away like winter snows under the warmth of a summer sun - away toward the north, away to the south, the east and the west they went, never more to return. An ancient Egyptian would have recalled the exodus of the Hebrews from his native land.",92 Contrast this description to the Journal's reports of "Hot Political Night[s]" and "fiery",93 speeches by Hague, and it is clear that the both papers understood the political importance of an audience's reaction.

Accusations of bossism flew back and forth between Hague and Wittpenn. Wittpenn sought to portray Hague as still a machine shill, this time the lackey of Newark's boss, James T. Smith, whom Hague had supported in an unsuccessful bid to block Wilson's presidential nomination. Hague compromised his image as a Progressive by failing to support Wilson in 1912, and in both 1913 elections Wittpenn rarely failed to mention that fact. Although he tried to denounce Hague as a demagogue, Wittpenn found himself compelled to answer Hague's attacks, thus forcing the language of the campaign into Hague's terms. ${ }^{94}$ Once Wittpenn referred to his candidates as "for want of a better designation [those who] were known as the organization candidates" "Hague's charges of bossism were all but confirmed.

Hague made political capital out of the mayor's having identified a slate of candidates for the commission. Using the campaign slogan "The Unbossed" in ads, he took Wittpenn's "bracketed" candidates as evidence of an attempt to control the election and continue Wittpenn's reign. ${ }^{96}$ Supporting Hague's attack, Vicar-General John A. Sheppard decried bracketed candidates "who acknowledge the call-up whistle of a boss." appealed across class lines, linking the middle-class fear of bossism to the working-class disdain for not being "your own man."

Hague's attacks against his former patron were outside the bounds of the older Horseshoe notions of political loyalty. He justified this breech of the ethical code of personal and party loyalty by insisting that Wittpenn had violated a higher trust. "If I am a traitor to Mayor Wittpenn, it is because Mayor Wittpenn is a traitor to the people of Jersey City.... He says I betrayed him. Maybe I did, but in betraying him I was loyal to the people who had elected me." 98 In this attack, Hague asserted his loyalty to the "people of Jersey City" - a broader echo of the old "Horseshoe against the world" ideology - while he appealed to Progressives with the suggestion that he was above mere politics and was instead driven by a more noble dedication to the citizenry.

\footnotetext{
92 "Audience Leaves When Hague Puts in an Appearance," Hudson Observer, April 9, 1913.

93 "Hot Political Night in the Horseshoe," Jersey Journal, June 4, 1913.

94 “Mayor Wittpenn in Hot Speech Attacks Hague," Jersey Journal, May 31, 1913.

95 Ibid.

96 Advertisement, Jersey Journal, May 29, 1913.

97 "Vicar-General Sheppard on Bossism," Jersey Journal, June 2, 1913.

98 “'Mayor Told Me I Was Too Particular,' Says Frank Hague,” Jersey Journal, June 7, 1913.
} 


\section{Not Doing "As Others Have Done"}

In the June election Hague received the second-highest vote total. With the defeat of four of five Wittpenn candidates, Hague catapulted to a position of power he had not previously enjoyed. Rather than promoting himself for mayor, however, Hague and the other commissioners appointed Michael Fagin, a reform Republican, to the mayoralty as an illustration of their nonpartisan ideology of civic government. Hague sought for himself the position of director of public safety, with control over both the police and fire departments. If Hague found ways to turn the custodianship and a seat on the street and water board into publicity, public safety gave him unparalleled opportunities to position himself in the public eye. According to Senator Joseph Tumulty, "This was his real source of power, his control of the Department of Public Safety." 99

Enhanced publicity permitted Hague to continue building his record as a Progressive. He insisted on rational, disciplined police and fire departments and warned that political favors, the primary political currency of the old order, would no longer be of value.

Hague announced his new ethical order: "The time has passed when it will be possible for you to go and see a politician and get away with violations of the law. I am not going to do as others have done." ${ }^{100}$ No longer, insisted Hague, would personal loyalty outweigh the commonweal, a dramatic statement from a former protégé of Bob Davis. Once the new commissioner began to purge both the fire and police departments of loafers and drunkards with sound political connections, however, his reforms came to represent an overthrow of the political ethics, that had, until that point, ruled both Hague and much of Jersey City. Hague accomplished this change without destroying his most basic - and most critical - base of support in the Horseshoe by dramatizing and personalizing each battle he fought in order to make it comprehensible in terms of the ethical tenets of the ethnic working class.

Hague centralized police control under his direct supervision. Citing a failure of officers to patrol their beats up to "one hundred per cent duty," he instituted a roaming squad of senior officers to ensure that the rank and file patrolled diligently. ${ }^{101}$ Eventually, this squad developed into the "Zeps," an elite core of officers directly under his control. The "Zeps," after "zeppelins," had orders to hover above the department and report back to Hague.

Part Marine dress guard, part internal affairs bureau, and part political spies, these officers became a signature of Hague's rule at the Jersey City Department of Public Safety. First among their duties was the ceremonial: officers escorted Hague at every public appearance from 1913 until 1947. According to Bob Leach, the Zeps acted "as a Palace Guard for Hague, surrounding him wherever he went, amid a hubbub of sirens, shining brass and jackbooted protocol." 102 These "Zeps," in addition to their role in

\footnotetext{
99 Tumulty, "Frank Hague," 4.

100 “'Hague Closes Four 'Movies' as Fire Traps," Jersey Journal, July 5, 1913.

101 "Hague Reads the Riot Act to the Police," Jersey Journal, April 20, 1914.

${ }^{102}$ Bob Leach, To Touch His Garment, Jersey City Historical Project, 1996.
} 
adding pomp and circumstance to Hague's comings and goings, also became his eyes and ears within the department and helped solidify his power among the fearful rank-and-file. According to Senator Tumulty, the Zeps were roughly equivalent to "a personal Gestapo of the type that Hitler had." 103

Hague used the martial drama of the uniformed forces to maximum effect. Mark Foster has described a 1914 Hague parade: "Seeing their well dressed firemen and policemen along with several recently purchased fire trucks aroused pride in the citizens of Jersey City. After the parade, Hague made a speech in which he carefully outlined his achievements as commissioner, lest the voters forget the real reason for the parade. Though the other commissioners also spoke, it was clearly Hague's show." ${ }^{104}$ As McGerr has noted, parades were an important part of the political landscape in the nineteenth century, and in Jersey City they continued to play this role into the twentieth. As both political event and popular entertainment, parades had long been popular in Jersey City. One 1911 cartoon from the Journal shows the citizenry of Jersey City enthusiastically parading along while the politician on the sidelines was unable to catch any attention. ${ }^{105}$ With or without political content (and they were rarely without), Jersey City was a city of parades.

Hague fused the excitement of the old Horseshoe rallies and parades with concrete evidence of his reforms - a well-disciplined force with modern equipment. He found a way to combine the popular activity with a direct illustration of his success as a reformer; such parades could be read with equal enthusiasm by all residents of Jersey City, whether from Horseshoe or Heights.

In addition to his activities reforming the department, Hague took an active role in the act of policing itself, and the Journal frequently reported arrests credited directly to Hague. Articles with such headlines as "Gangs in Autos Gathered in by Commissioner Hague"106 and "Hague in Chase after a Driver," elevated Hague's public image from crusading director of public safety to Jersey City's own supercop, roving the city to protect its citizens. $^{107}$

One incident stands out in Hague's role as Jersey City's premier police officer. After attending church on Good Friday in 1916, Frank Kenny, a well-known Horseshoe resident, was gunned down in front of his young wife by Michael Rombollo, an Italian strikebreaker. Taking to the streets, the grief-stricken Irish community attacked any Italian close to the description of the killer. ${ }^{108}$ Hague, who had received his start in politics from Kenny's father, immediately pledged that he would bring the murderer to justice. ${ }^{109}$ When a hat dropped near the scene of the crime led to a Newark address, Hague personally rode along with police to apprehend the killer. While the police entered

\footnotetext{
103 Tumulty, "Frank Hague," 4.

${ }^{104}$ Foster, "Early Career," 99.

105 “Can’t You See I’m Busy!” Jersey Journal, October 6, 1911.

106 "Gangs in Autos Gathered in by Commissioner Hague," Jersey Journal, September 23, 1914.

107 "Hague in Chase after a Driver," Jersey Journal August 19, 1914.

${ }^{108}$ Leach, To Touch His Garment, 4.

109 “Funds to Catch Kenny's Slayer,” Jersey Journal, April 26, 1916.
} 
the empty apartment, Hague noticed a suspicious man at a corner store. When the man ran out, Hague gave chase. Rombollo drew his revolver, but Hague leapt on him, disarmed him, and held him until the police regulars arrived to assist. ${ }^{110}$

Hague's heroics proved a publicity bonanza. Even the oft-critical Hudson Observer raved, "Director of Public Safety Frank Hague, who arrested the slayer in Newark, is the lion of the hour, and the members of his department, as well as the general public are loud in their praise of his bravery." "But Hague got more out of his tussle with Rombollo than mere public adulation. In addition to the acclaim for his bravery, the incident afforded Hague a justification for his attempts to reform the police department. According to the Journal editors, "It is rarely that the head of a police department personally goes after a dangerous criminal and has the enviable distinction of running down the offender. The bravery of Director Hague cannot be questioned. He has set a splendid example for the men of the Jersey City Police Department. He does not ask his men what he will not do himself."112 Before Rombollo's arrest, police leadership accused Hague of not being one of them, of not understanding the problems or culture of the force. Afterward, the credibility of those who challenged Hague's prerogative as the city's premier cop was shaken.

Grumblers and naysayers suggested that Hague orchestrated the details of Rombollo's capture for his own glory; he had been similarly accused in his arrest of two burglars three years earlier. ${ }^{113}$ Whether or not he did so in either case remains unverifiable, but, even if both incidents are genuine evidence of Hague's bravery in the face of danger, it is significant that he actively sought the opportunity to grab headlines by personally engaging in police work. No evidence exists to suggest that Hague could have somehow rigged his fight with Rombollo. By riding along, however, Hague sought to include himself publicly in the arrest, even if he had not expected to take a starring role. Even when not directly involved in the action, Hague brought himself into the limelight on any major arrest, thus pioneering the modern practice of appearing by the bedside of any officer injured in the line of duty. ${ }^{114}$

As director of public safety, Hague increasingly invoked securing the safety of women and children in his pleas for reform. Demanding a crackdown on "rowdyism" and youth gangs, he insisted, "without fear or favor I will continue to perform my duties and do my best to make Jersey City a safe place to live. Citizens, and especially women and children, must be free from insult and attack in public places."115

\footnotetext{
110 “Facing Drawn Revolver, Hague Overpowers and Arrests Kenny’s Slayer,” Jersey Journal, April 28, 1916.

111 “Quick Capture of Murderer Evokes Praise,” Hudson Observer, April 29, 1916.

112 “Splendid Police Work," Hudson Observer, April 29, 1916.

${ }^{113}$ Bob Leach, Director, Jersey City Historical Project, interview with author, May 1997; "Hague Denies Making Threat to Noonan," Jersey Journal, January 9, 1914.

114 "Policeman, Though Shot, Pursues Thief, Then Goes to Hospital," Jersey Journal, June 9, 1914; "Hague Praises Brave Cop," Jersey Journal November 21, 1914.

115 “'Rowdyism Must be Suppressed' Says Hague,” Jersey Journal, September 10, 1914.
} 
A pledge to protect families was fundamental to his crackdown on police drunkenness. When commissioner Brensinger objected to a strict fine Hague imposed on an officer with a family, Hague retorted, "I agree with you that the punishment is severe... but we have to remember that this man was not thinking about his own children, nor about your children or my children when he failed to do his duty." $" 16$

Hague's crusade to protect women is best exemplified by his attacks on the "back room menace," the practice of permitting women, not normally allowed in saloons, into secret back rooms. Shortly after taking up the post of director of public safety, Hague warned his officers, "I am determined.. to get rid of back rooms attached to saloons, where men and women assemble and remain for hours drinking. Many young girls are ruined in this way, and I will not tolerate such a condition for a minute. ${ }^{" 117}$ He returned to this theme a year later when he warned, "I do not want these conditions to exist in any precinct in the city and I feel that in certain sections of the city, women are being tolerated in saloons and are permitted to become intoxicated, having been seen to leave saloons at all hours." 118 Hague promised to charge police captains not diligent in enforcement. ${ }^{119}$

Hague moved to close firetrap movie theaters in a long and public crusade. ${ }^{120}$ "I have not slept comfortably a single night since I received the report... on the condition of the moving picture show places in this city... After what I learned, I would feel a murderer if I had permitted some of the places to remain open a minute and any fatality had occurred." 121 He went on to note that the imperative for closing was doubly strong because "principally women and children... are the heaviest patrons of the picture shows." "122 He moved to protect the honor of young women by limiting the number of licensed dance halls in the city and by keeping close police watch over the few he left open. $^{123}$

The defense of women and families was regarded as a positive reform in both of his constituencies. What Senator Tumulty described as Hague's "Irishman's respect for womanhood" was in fact, a trait in Haig that held broad-based appeal. His protection of women was praised by the Irish Horseshoe residents as well as by the WASP reformers in Jersey City Heights. ${ }^{124}$

Hague's sweeping reforms as director of public safety did not go unchallenged. The Policemen's Benevolent Association (PBA), long a strong political force in Jersey City, sought to check Hague's reorganization of the police department. As with his earlier fights, Hague simply appealed to the public and characterized the battle in personal

\footnotetext{
116 “Back Hague in Punishing Drunken Cops,” Jersey Journal, February 4, 1915.

117 “Clean Out the Backrooms, Hague Tells Captains," Jersey Journal, June 25, 1913.

118 "Hague Repeats Order about the Back Rooms," Jersey Journal, August 6, 1914.

119 Ibid.

120 "Hague Closes Four "Movies" as Fire Traps"; "Hague to Put in New Ordinance for the Movies," Jersey Journal, April 20, 1914.

121 "Hague Closes Four 'Movies' as Fire Traps.”

122 Ibid.

123 “Hague Stops New Dance Hall Move," Jersey Journal, April 19, 1916.

124 Tumulty, "Frank Hague," 2.
} 
terms. In an effort to seize control of internal affairs trials, Hague nearly came to blows with John Burke, the state president of the PBA. ${ }^{125}$ But when Jersey City Police Chief Monahan publicly derided Hague's leadership at a PBA dinner ${ }^{126}$, Hague had found his enemy. Hague suspended Monahan and brought him up on charges of insubordination. ${ }^{127}$ Although Monahan was eventually acquitted and reinstated, he and Hague continued to vilify one another for several years.

Returning to his dramatic threats to quit in his PBA fight, Hague shouted, "I'd sooner be out of the board than be insulted any longer by policemen on the street. It's an outrage and a disgrace to the city. The PBA are not going to run me. They have tried hard. They have called me everything." 128 The fight with the PBA raged for years and became central in the commission government election in 1917. Hague attacked the association relentlessly, both on the stump and through the legislature in Trenton. For Hague, however, the two were seldom separate. In March 1917, after a long battle in the legislature over a bill to limit Hague's judicial power in the police department ended in a victory for Hague, the state president of the PBA conceded, "The bill was killed by too much publicity." 129 Just as with his previous fights, when he could not get his way Hague went to the public with the issue; he relied on his skill as an orator and a manipulator of public opinion to win the day.

Hague sought to appropriate the symbolic assets of the PBA by suggesting to the PBA band that they rename themselves the "Jersey City Police Band." 130 The move to control the musicians illustrates the continuing value of entertainments as a political tool. Hague understood from the early days in the "Shoe that every performance by the band under the auspices of the PBA was a piece of political theater that directly challenged his authority. By controlling the band, he could co-opt its political value, both as symbol and as an effective tool to drum up a crowd.

Once Hague had won the right to conduct police trials himself, he exploited this venue to publicize his department cleanup in dramatic fashion. He held trials of more than two hundred officers for various offenses. ${ }^{131}$ While trying former PBA head John Brennan, Hague insisted that he heard Brennan mumble a threat from the witness stand and flew into a rage detailed in dramatic form in the following morning's Journal. ${ }^{132}$

\footnotetext{
125 "Hague and P.B.A. Head Almost Come to Blows at Hearing on Bill for Cops' Trials," Jersey Journal March 25, 1915.

126 "Hague to Call Monahan to Account," Jersey Journal, May 4, 1915.

127 "Hague Acts against Monahan," Jersey Journal, May 5, 1915; "Monahan is Suspended as Chief," Jersey Journal, May 13, 1915.

128 "Hague Gets Power to Conduct Police Trials, After All," Jersey Journal, April 23, 1915.

129 "Hague Wing Clipper Is Dead,” Jersey Journal, March 22, 1917.

130 “The Police Band May Leave P.B.A.," Jersey Journal, November 10, 1913.

131 “Hague Starts Trials, Former P.B.A. Head Gets 60 Days,” Jersey Journal, April 28, 1915; "Hague Tries 75 Cops; Is Lenient with All but Six," Jersey Journal, April 28, 1915; "Hague Tries Second Batch of Policemen," Jersey Journal, April 30, 1915.

132 “Hague Starts Trials, Former P.B.A. Head Gets 60 Days,” Jersey Journal, April 28, 1915.
} 


\section{Rallying around the Hague Banner}

Hague's four-year term as commissioner was due to end in 1917. By late 1916, he began campaigning for the upcoming election. He continued to expand his appeal by linking himself to both Republican support ${ }^{133}$ and organized labor. ${ }^{134}$ With his popularity at its high-water mark, Hague cast his net wider than in any previous election.

The 1917 election that actually made Hague mayor was largely anticlimactic. Popular for his reforms as commissioner of public safety and still riding the crest of praise from the dramatic end to the Kenny murder investigation, Hague's return to city hall was practically a foregone conclusion. The only significant opposition for control of the commission came from a badly weakened Wittpenn and from former Chief Monahan, who attacked Hague for his iron-fisted rule of the police department.

Hague moved to block Monahan's candidacy for commissioner by arguing that running while still chief constituted a violation of the police manual. Hague portrayed the issue as an attempt to keep politics out of law enforcement. Said Hague, "I have kept politics out of the police department and I am going to keep it out." 135

Although accusations of bossism plagued Hague's campaign, he countered them by insisting that the PBA was the real political machine. ${ }^{136}$ After the Rombollo affair, Monahan's accusations of Hague's failings in the police department fell on deaf ears. Full-page newspaper ads taken out Hague summarized the election as "the P.B.A. vs. The People - Which Do You Want?"137 The newspapers echoed Hague's characterization of the election. The Hudson Observer editorialized, "the campaign against Hague was anticipated. The greatest of his many achievements for the public weal was reclaiming the police department and restoring its service to the people. The political clique within the department is trying to beat him."138 As in previous political battles, Hague dramatized the details of his fight for the public to watch and enjoy. The Hudson Observer characterized the election as "Commissioner Hague's Manly Fight." 139 In another editorial, the Observer again echoed Hague's presentation of his own manly battles: "People like a fighter for a good cause; hence, the voters of Jersey City are rallying around the Hague banner. That's why he will win."

Hague did win. His broad call for support had been heard, as he polled well both in working-class ethnic and Protestant middle- and upper-class wards; Hague ran a close second in the citywide vote totals to A. Harry Moore. ${ }^{141}$

\footnotetext{
133 “Hague Looks for G.O.P. Support,” Jersey Journal, May 7, 1917.

134 “Hague and Labor" (advertisement), Jersey Journal, May 5, 1917.

135 "Hague Bars Chief Manahan as Candidate," Jersey Journal, October 11, 1916.

136 “G.O.P. Candidates Call Hague 'Boss,"” Jersey Journal, October 31, 1916; "Monahan Calls Hague Boss of Police Machine,” Jersey Journal, May 3, 1917.

137 Advertisement, Jersey Journal May 3, 1917.

${ }^{138}$ Editorial, Hudson Observer, May 5, 1917.

139 “The True Inside History of Commissioner Hague's Manly Fight,” Hudson Observer, May 4, 1917.

140 "Why Commissioner Hague Is Popular," Hudson Observer, May 3, 1917.

141 “The Vote by Wards, On First Choice,” Jersey Journal, May 9, 1917.
} 
When the new commissioners met for the first time, they named Hague mayor, the post he occupied for the next thirty years. ${ }^{142}$ Although his tenure as mayor brought Hague national notoriety, it is his early career that shows the development of the political skills that catapulted him to power. Hague developed a combined appeal. By simultaneously targeting both his core ethnic and working-class constituency and the reform-minded, native-born middle class, Hague embraced two distinct political moralities. Hague used his dramatic flair for self-representation and self-lionization to ensure that every move would be watched by the public, and thus he dictated the terms of his own media portrayal. His constant molding of his public persona ensured that the public would view Hague in terms appropriate for every audience. In the words of a later mayor of Jersey City, "Because he made good copy, the Journal began to hang on every move made by Hague."

It will be impossible for Jersey City to forget the Hague years. The city is dotted with buildings and monuments erected during his mayoralty, including the massive Jersey City Medical Center that continues to dominate the skyline. But just as Jersey City bears the physical legacy of Frank Hague's reign, so too do its politics. Hague etched his legacy on the political landscape of Jersey City. He reshaped both the substance and symbols of the political process. By translating reform politics into the theatrical style of Horseshoe political pageantry, Hague forged a single political language that spoke to all of the city.

Hague personalized every political battle and dramatized even mundane and abstract policy as a vivid struggle between men. Every issue became translated into a political boxing match - occasionally literally - and each issue became of test of Hague's manhood. Hague lifted tropes of manhood and personal struggle from the ethnic politics of his youth and applied them to the issues that excited middle-class Progressives. Over the course of his early career, Hague developed a political style that was decipherable to both the personalized ethics of the Horseshoe and the depersonalized "good government" ideology of Jersey City Heights.

Although in later years Hague was frequently thwarted in attempts to expand his power beyond New Jersey's borders, his legacy - and the lessons to be drawn from it - are writ large on the American political landscape. Often described as an archetype of the political boss, Hague's rise affords scholars a window into the cultural processes necessary for such a system to develop. Even more important, the sort of cross-ethnic and cross-class coalition building Frank Hague pioneered remains a critical part of today's urban political landscape. The lessons of Frank Hague's early career are as resonant at the beginning of the twenty-first century as they were at the dawn of the twentieth.

142 “Hague, Mayor; Acclaimed as County Leader," Jersey Journal, May 11, 1917.
${ }^{143}$ Smith, Powerticians, 53. 
Raffety 